\title{
Postharvest quality of achachairú (Garcinia gardneriana) stored at ambient temperature ${ }^{1,2}$
}

\author{
Marlyn Cotty-Más ${ }^{3}$, Rosa N. Chávez-Jáuregui ${ }^{4}$ \\ and Linda Wessel-Beaver ${ }^{5}$
}

J. Agric. Univ. P.R. 103(2):155-172 (2019)

\begin{abstract}
Achachairú is a tropical fruit that is being evaluated for its potential as a new fruit crop for Puerto Rico. More information is needed concerning postharvest aspects of this fruit. In this paper we describe the physical and chemical characteristics of achachairú during storage at ambient temperature. During each of three harvest years, 75 to 100 fruits were harvested, washed and dried, then divided into five groups. Each group was placed in an open cardboard box and randomly assigned to one of five storage treatments $\left(0,5,10,15\right.$, and 20 days at $25 \pm 2{ }^{\circ} \mathrm{C}, 75 \pm 5 \%$ relative humidity). Physical and chemical properties, including sugar content, were determined for each storage period. Sensory panels evaluated fruits after 0 and 15 days of storage. Over the 20-day storage period fruit weight, size (length and diameter), firmness and pulp weight decreased by $1.5 \%$ to $2.5 \%$ per day. The rating of external fruit appearance (evaluated on a hedonic scale) deteriorated in a curvilinear fashion over time, initially changing little, and then showing increased deterioration (dark spots and wrinkling) starting at $\mathbf{1 5}$ days post storage. Total soluble solids ( ${ }^{\circ} \mathrm{Brix}$ ) (TSS) increased over time by 0.8 to $1.6 \%$ per day, while total titratable acid (TTA) decreased 1.4 to $3.0 \%$ per day, resulting in an increase of the sugar-acid ratio (TSS/TTA) of 2.1 to $12.4 \%$ per day over 20 days of storage. Sucrose was the most abundant sugar $(7.19 \mathrm{~g} / 100 \mathrm{~g})$, followed by fructose $(3.38 \mathrm{~g} / 100 \mathrm{~g})$ and glucose $(3.18 \mathrm{~g} / 100 \mathrm{~g})$. Panelists judged the sweetness, aroma, acidity, juiciness and overall flavor not to have changed after 15 days of storage. Results of this study suggest that achachairú can be stored at ambient temperature for 15 days and maintain fruit quality acceptable to the consumer.
\end{abstract}

${ }^{1}$ Manuscript re-submitted to Editorial Board 28 January 2019.

${ }^{2}$ This research was supported by funds from the United States Department of Agriculture, National Institute of Food and Agriculture, Hatch Program. We appreciate the help of the late Dr. Felipe Osborne who supplied fruits for the study.

${ }^{3}$ Ex-graduate student, Science and Food Technology Program, University of Puerto Rico, Mayagüez Campus.

${ }^{4}$ Professor, Science and Food Technology Program and Department of Agroenvironmental Sciences, University of Puerto Rico, Mayagüez Campus, Mayagüez, Puerto Rico 00681. e-mail: rosa.chavez@upr.edu

${ }^{5}$ Professor (retired), Department of Agroenvironmental Sciences, University of Puerto Rico, Mayagüez Campus, Mayagüez, Puerto Rico 00681. 
Key words: Garcinia spp., G. humilis, physicochemical characteristics, sugars, postharvest quality, tropical fruits

\section{RESUMEN}

Calidad poscosecha de achachairú (Garcinia gardneriana) almacenado a temperatura ambiente

EI achachairú es una fruta tropical que está siendo evaluada por su potencial como un nuevo cultivo frutícola para Puerto Rico. Se necesita más información sobre los aspectos poscosecha de esta fruta. En este artículo presentamos las características físicas y químicas de achachairú durante el almacenamiento a temperatura ambiente. Durante cada uno de los tres años de cosecha, se cosecharon, lavaron y secaron de 75 a 100 frutas, luego se dividieron en cinco grupos. Se ubicó cada grupo en una caja de cartón sin cerrar y se asignó al azar a uno de los cinco tratamientos de almacenamiento (durante $0,5,10,15$ y 20 días a $25 \pm 2{ }^{\circ} \mathrm{C}, 75 \pm 5 \%$ de humedad relativa). Las propiedades físicas y químicas, incluido el contenido de azúcar, se determinaron para cada período de almacenamiento. Los paneles sensoriales evaluaron las frutas después de 0 y 15 días de almacenamiento. Durante el período de almacenamiento de 20 días, el peso, el tamaño (longitud y el diámetro) de la fruta, la firmeza y el peso de la pulpa disminuyeron de 1.5 a $2.5 \%$ por día. La clasificación de la apariencia externa de la fruta (evaluada en una escala hedónica) se deterioró de manera curvilínea con el tiempo, inicialmente cambió poco y luego mostró un mayor deterioro (manchas oscuras y arrugas) a partir de los 15 días posteriores al almacenamiento. Los sólidos solubles totales ( ${ }^{\circ}$ Brix) (TSS, por siglas en inglés) aumentaron con el tiempo entre un 0.8 y un $1.6 \%$ por día, mientras que el ácido titulable total (TTA, por siglas en inglés) disminuyó entre un 1.4 y un 3.0\% por día, lo que resultó en un aumento en la relación azúcar-ácido (TSS/TTA) de 2.1 a $\mathbf{1 2 . 4 \%}$ por día durante 20 días de almacenamiento. La sacarosa fue el azúcar más abundante $(7.19 \mathrm{~g} / 100 \mathrm{~g})$, seguido de fructosa $(3.38 \mathrm{~g} / 100 \mathrm{~g})$ y glucosa $(3.18 \mathrm{~g} / 100 \mathrm{~g})$. El panel sensorial consideró que la dulzura, el aroma, la acidez, la jugosidad y el sabor en general no habían cambiado después de 15 días de almacenamiento. Los resultados de este estudio sugieren que el achachairú puede almacenarse a temperatura ambiente durante 15 días y mantener la calidad de la fruta aceptable para el consumidor.

Palabras clave: Garcinia spp., G. humilis, características fisicoquímicas, azúcares, calidad poscosecha, frutas tropicales

\section{INTRODUCTION}

Achachairú is a tree species of tropical regions of South America. The edible white, fleshy pulp usually surrounds one or two seeds and has a pleasing sweet-sour flavor. Achachairú is a member of the genus Garcinia (previously Rheedia) and originates in the eastern part of Bolivia. Almost all species of this genus are of Asian origin, including the well-known mangosteen ( $G$. mangostana). In the Americas, various species of Garcinia are known from places as diverse as Guyana, Panama, Dominica, Trinidad, Grenada and Haiti (Lim, 2012). 
Considerable confusion surrounds the correct botanical classification of achachairú. Ardaya (2009), working in Bolivia, classified the achachairú fruits used in his study as G. humilis. Da Fonseca (2012), working in Brazil, used the same species name [G. humilis (Vahl) C. D. Adam]. However, a review of the botanical literature suggests that this designation might be incorrect and that G. gardneriana (Planch. \& Triana) Zappi might be the more appropriate name for what is generally known in Spanish as achachairú and sometimes known in Portuguese as bacupari (see multiple references in International Plant Names Index, 2019). Lim (2012) and Duarte (2011) recognized other synonyms of $G$. humilis including $R$. achachairu Rusby and $R$. lateriflora L. In Puerto Rico, Barragán-Arce (2011) looked at floral structures in the same trees used for our study. He noted that these trees had been previously referred to as G. brasiliensis or G. laterifolia. However, he concluded that the flowers most resembled those of $G$. gardneriana because the carpel number was three rather than the four carpels found in $G$. brasiliensis. Various international plant species databases indicate that some, if not all, of these species names are synonymous. Based on our review of the literature, and especially in consideration of the work of Barragán-Arce (2011), we have chosen to accept the designation G. gardneriana (Planch. \& Triana) Zappi.

Achachairú is widely produced and commercialized in Bolivia and Brazil (Barbosa et al., 2008). The largest commercial production is in northern Australia where the common name is achacha (Achacha Fruit Management of Australia, 2013). About 16,000 trees have been in production since 2009 (International Tropical Fruit Network, 2019). They are expected to produce about $250,000 \mathrm{~kg}$ of fruit in the 2019 production year. Individual trees can produce up to $100 \mathrm{~kg}$ of fruit and the fruit sells for $\$ 10$ to $\$ 25$ per kilogram.

The fruit has a low fat and protein content (Janick and Paull, 2008). In Bolivia it is considered to have curative digestive and laxative properties and has been used to treat gastritis, rheumatism and inflammation (Barbosa and Artiole, 2007). Its pulp is used in the preparation of jelly, juice, sorbet and ice cream, and its rind has been used to make liquors and wine (Lim, 2012).

Very limited studies are found in the literature concerning the effects of storage on fruits of achachairú. Janick and Paull (2008) report that, for fresh-fruit consumption, achachairú keeps for one week at room temperature and for two to three weeks for industrial use. According to Achacha Fruit Management of Australia (2013), fruits can be maintained at $20^{\circ} \mathrm{C}$ for several days in an open container and several weeks in a closed container or bag. Duarte (2011) reported that $12^{\circ}$ $\mathrm{C}$ is an adequate temperature for storage of achachairú but found that 
fruit damage occurs at $6^{\circ} \mathrm{C}$. Wills et al. (1982) indicates that mechanical damage reduces visual quality by leaving spots and wounds that increase fruit metabolism and transpiration.

The unique sensorial characteristics of achachairú have awakened an interest among local growers to consider the possibility of commercializing this fruit crop in Puerto Rico. It is important to document postharvest changes that occur in fruits in order to define management practices that will provide the consumer with a quality product. Therefore, our objective was to characterize the physical and chemical changes that occur in achachairú during storage at room temperature.

\section{MATERIALS AND METHODS}

Mature fruits (full orange color) were harvested from a private farm in Las Marías, Puerto Rico, from June to August of 2012, 2013 and 2014. Hand harvesting was carried out in order to minimize mechanical damage. Harvesting was done early in the morning. In each year's harvest, fruits of a uniform size (about $4 \mathrm{~cm}$ in diameter) were selected. All physical and chemical evaluations were carried out in laboratories of the Food Science and Technology program of the College of Agricultural Sciences, University of Puerto Rico, Mayagüez Campus (UPRM). In the laboratory fruits were washed with water and dried, then divided into five groups of 15 (2012) or 20 (2013 and 2014) fruits. Fruits were placed uncovered in cardboard boxes and each group was randomly assigned to one of five storage periods $[0,5,10,15$ and 20 days of storage at $25 \pm 2^{\circ} \mathrm{C}, 75 \pm 5 \%$ relative humidity $(\mathrm{RH})$ ]. Day 0 (0 days of storage) corresponded to the day of harvest.

After each storage time, the external appearance of the fruit rind was evaluated using the 0 to 4 scale of Fontenele (2007), where $0=a b-$ sence of dark spots and wrinkles, $1=$ few dark spots, $2=$ many dark spots and some wrinkles, $3=$ many dark spots and wrinkles and $4=$ completely dark and wrinkled. Fruit length, diameter and weight were measured. Fruit firmness [force in Newtons (N) needed to penetrate the fruit rind] was measured with a texturometer (Texture Analyzer model TA.XT2, Texture Technologies, MA, USA $)^{6}$ with a $2 \mathrm{~mm}$ stainless steel tip. Pulp thickness was determined by averaging four measurements taken between the fruit poles and equator using a Vernier digital caliper (Mitutoyo, Japan). Pulp weight was measured and the number of large

${ }^{6}$ Company or trade names in this publication are used only to provide specific information. Mention of a company or trade name does not constitute an endorsement by the Agricultural Experiment Station of the University of Puerto Rico, nor is this mention a statement of preference over other equipment or materials. 
(fully formed) and atrophied (small) seeds were counted as suggested by Cavalcante et al. (2006).

For each harvest year and storage time, chemical analyses were carried out using a composite of pulp from three fruits. Total soluble solids (TSS) were measured as ${ }^{\circ}$ Brix with a digital refractometer (model PAL-BX/RI, ATAGO Co., LTD, Tokyo, Japan). The $\mathrm{pH}$ was measured (model Docu-pH Meter, Sartorius, New York, USA.). Total titratable acid (TTA) was determined by titration with $0.1 \mathrm{~N} \mathrm{NaOH}$ to a $\mathrm{pH}$ of 8.2 and expressed as a percentage of citric acid. Maturity relationship was established as the ratio between TSS and TTA.

Sugars were measured only in years 2013 and 2014. For reducing sugars percentage, a $2.5 \mathrm{~g}$ sample was placed in either a $50 \mathrm{~mL}$ or 100 $\mathrm{mL}$ volumetric flask, depending on the concentration of sugars. The flask was filled with distilled water and the contents vacuum filtered with Whatman ${ }^{\circledR} \# 4$ filter paper. For each sample, a Lane-Eynon titration was done in triplicate in combination with Association of Official Analytical Chemists (AOAC) method 923.09C for the concentration of unknown sugars (Horwitz and AOAC International, 2003). The percentage of reducing sugar in a sample was calculated using AOAC table 930.44. Sucrose, fructose and glucose were determined following the method of Salman et al. (2011). High performance liquid chromatography (HPLC) was used with a refraction index detector (RID) model 1100, and a thermostatted column compartment (TCC) model 1200 (Agilent Technologies, Santa Clara, California, USA) and a Waters Sugar Pak ${ }^{\mathrm{TM}}$ II column (Waters Corporation, Milford, MA, USA). Sugars were separated using a $300 \mathrm{~mm}$ x $6.5 \mathrm{~mm}$ Waters Sugar Pak ${ }^{\mathrm{TM}}$ I column (Waters Corporation, Milford, MA, USA). A 0.0001 M Ca-EDTA solution (Millipore-Sigma, St. Louis, MO, USA) was used for the mobile phase at $45^{\circ} \mathrm{C}$ with $0.5 \mathrm{~mL} / \mathrm{min}$ flow. Oven temperature for the TCC was set to $80^{\circ} \mathrm{C}$ and the injection volume to $10 \mu \mathrm{L}$.

For each storage time and harvest year, a proximate analysis was conducted on a composite sample of 10 fruits. A total of nine determinations was taken on this bulk sample. Pulp composition was determined following AOAC methods (Horwitz and AOAC International, 2003). Moisture, protein, ash, fiber and fat were determined following AOCS (American Oil Chemists' Society, 2004) methods. Results for the analysis of protein, ash, fat and fiber were corrected for the percentage of volatile compounds lost during the drying of samples. The percentage of available carbohydrates was determined by the difference between $100 \%$ and the sum of the percentages of moisture, protein, ash, fiber and fat.

For the 2012 harvest, consumer acceptability of fresh fruits (0 days of storage) was evaluated by 50 untrained volunteer panelists using 
a 9-point hedonic scale (Meilgaard et al., 2007), where 1=dislike very greatly, $5=$ neither like nor dislike, and $9=$ like very greatly. For fruits stored 0 or 15 days after the 2013 and 2014 harvests, a panel of 16 consumers evaluated sweetness, aroma, acidity, juiciness and general flavor, using a 7-point hedonic scale (1=dislike extremely, 4=neither like nor dislike, and $7=$ like extremely). The sensory analysis was reviewed and approved by the Institutional Review Board of the UPRM.

Regression was used to analyze data collected over the 20-day storage period. Linear and quadratic models were tested. With the main exception of external fruit appearance, the addition of the quadratic term did not usually improve the fit of the model in the regression analyses of the effect of days of storage on the various physical and chemical attributes of achachairú fruit. Therefore, a quadratic model was used for external fruit appearance while only estimates from linear regression appear in tables for the other traits. For traits analyzed by linear regression, the means that are reported correspond to adjusted means at day 0 , which are equivalent to the intercept of the linear regression line.

\section{RESULTS AND DISCUSSION}

\section{External fruit appearance}

The effect of days of storage on the external appearance of achachairú fruit was curvilinear, with little change in appearance occurring in the first five days of storage (scores of 0 or 1 , no or few spots or wrinkles), and deterioration increasing more rapidly over the next 15 days (Figure 1). After 20 days of storage, no fruit had a score of 0 or 1 , and more than $50 \%$ of the fruit had scores of 3 (large number of dark spots and severe wrinkling) or 4 (fruit severely wrinkled and entire surface covered with dark spots).

Teixeira et al. (2005) observed that in bacuri (Platonia insignis), a fruit related to achachairú, fruit shrinkage resulting in wrinkling was the most important factor impacting appearance although they also indicated that dark spots play a role. A weight loss of 5\% is enough to cause shrinkage in fruits and vegetables, and this shrinkage affects quality (Pantastico et al., 1979). Thorp and Bieleski (2002), working with another fruit from the American tropics, feijoas (Acca sellowiana), noted that changes in fruit appearance can occur during fruit maturation and senescence as well as a result of mechanical damage during harvest and postharvest operations. Browning of the fruit surface occurs when epidermal tissues break, and oxygen is introduced allowing activation of enzymes. The enzymes involved in surface blotching or 


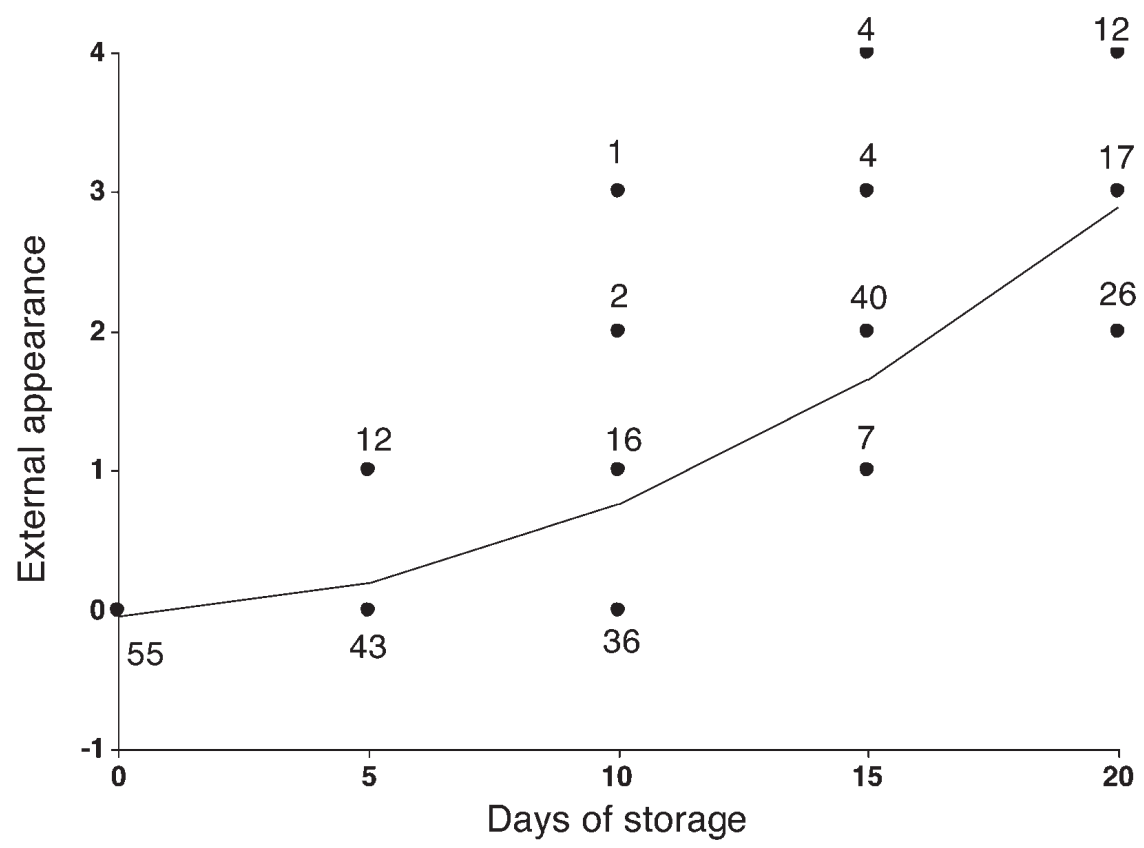

Figure 1. Quadratic regression analysis (Appearance $=-0.043+0.013$ Days + 0.007 Days $\left.^{2}\left[R^{2}=0.741 ; p=<0.0001\right]\right)$ of the effect of days of storage at $25^{\circ} \mathrm{C}$ and $75 \%$ relative humidity on the external appearance of fruits of achachairú (Garcinia gardneriana) harvested in 2012, 2013 and 2014 in Las Marías, Puerto Rico. (Scoring scale: 0 to 4, where $0=$ no defects). Numbers within the graph refer to the number of fruits with the indicated score. For each storage period, 15 fruits were sampled in 2012, and 20 fruits each in 2013 and 2014 ( $\mathrm{n}=55$ for each storage period).

browning include polyphenol oxidases, polyphenolases and phenolases (Gutiérrez, 2000). The action of polyphenolases generally diminishes the attractiveness of fruits although it can be beneficial in some cases such as with tea and coffee (Deman, 1999).

\section{Physical attributes of the fruit}

Days of storage almost always exhibited a significant linear effect on achachairú fruit traits (with the exception of fruit length in 2012 and fruit diameter in 2014) (Table 1). While there were some differences among years, for a given trait the direction of the response (slope) was always negative (indicating poorer quality over time), and the magnitude of the response was usually similar. Nevertheless, for most traits there was considerable unexplained variability in the regression analyses. The highest coefficient of determination, for rind weight in 2012 , was $\mathrm{R}^{2}=0.56$, indicating that only $56 \%$ of the variation in this trait could be explained by the linear regression of rind weight 
TABLE 1.-Parameter estimates (intercept, slope), coefficients of determination $\left(R^{2}\right)$ and probabilities of the linear regression analysis of physical traits of fruits of achachairú (Garcinia gardneriana) harvested in 2012, 2013 and 2014 in Las Marías, Puerto Rico, and stored for 0, 5, 10, 15 and 20 days at $25^{\circ} \mathrm{C}$ and $75 \%$ relative humidity.

\begin{tabular}{lccccc}
\hline Trait $^{\mathrm{z}}$ & Year & Intercept $^{\mathrm{y}}$ & Slope & $\mathrm{R}^{2}$ & Probability \\
\hline Fruit weight (g) & 2012 & 44.86 & -1.06 & 0.51 & $<0.0001$ \\
& 2013 & 53.12 & -1.10 & 0.51 & $<0.0001$ \\
& 2014 & 45.51 & -0.71 & 0.38 & $<0.0001$ \\
Fruit length (mm) & 2012 & 55.45 & -0.12 & 0.04 & 0.1032 \\
& 2013 & 56.06 & -0.20 & 0.13 & 0.0003 \\
Fruit diameter (mm) & 2014 & 56.70 & -0.18 & 0.09 & 0.0025 \\
& 2012 & 41.05 & -0.24 & 0.24 & $<0.0001$ \\
Firmness (N) & 2013 & 44.23 & -0.19 & 0.18 & $<0.0001$ \\
& 2014 & 41.23 & -0.10 & 0.08 & 0.2657 \\
& 2012 & 16.15 & -0.25 & 0.19 & $<0.0001$ \\
Rind weight (g) & 2013 & 13.51 & -0.30 & 0.47 & $<0.0001$ \\
& 2014 & 15.58 & -0.24 & 0.34 & $<0.0001$ \\
& 2012 & 20.66 & -0.56 & 0.56 & $<0.0001$ \\
Rind thickness (mm) & 2013 & 21.93 & -0.52 & 0.45 & $<0.0001$ \\
& 2014 & 20.77 & -0.39 & 0.47 & $<0.0001$ \\
& 2012 & - & - & - & $<0.0001$ \\
Pulp weight (g) & 2013 & 3.05 & -0.06 & 0.37 & $<0.0001$ \\
& 2014 & 3.35 & -0.05 & 0.42 & $<0.0001$ \\
& 2012 & 13.54 & -0.33 & 0.37 & $<0.0001$ \\
& 2013 & 16.79 & -0.37 & 0.46 & $<0.0001$ \\
& 2014 & 14.11 & -0.25 & 0.44 & $<0.0001$ \\
\hline
\end{tabular}

At the end of each of the five storage periods, 15 (2012) or 20 (2013 and 2014) fruits were sampled. yThe intercept is equivalent to the adjusted mean at 0 days of storage (intercept of linear regression model).

to days of storage. Unknown factors apart from number of days in storage clearly played a role in changes in fruit traits over time. Initial variability in fruit weight or size may have contributed to the observed variability. Although an attempt was made to sample fruits of a similar size, when sampling 75 (2012) or 100 fruits (2013 and 2014) it is unlikely that all fruits will initially be the same.

Over the three years of the study, weight loss averaged 0.71 to 1.10 g per fruit per day, resulting in an overall weight loss of more than $40 \%$ after 20 days (Table 1). On average, fruit length diminished by $0.12 \mathrm{~mm}$ to $0.20 \mathrm{~mm}$ per day over 20 days of storage, although the loss in length was not significant in 2012. Average fruit diameter also diminished over the study period by $0.10 \mathrm{~mm}$ to $0.24 \mathrm{~mm}$ per day, but the loss was not significant in 2014. Overall, these losses correspond to about $4 \%$ to $7 \%$ of length and $9 \%$ to $12 \%$ of diameter over the 20 -day period. As 
is typical in all photographs we have seen of achachairú fruits, in our study fruits were slightly elongated as evident by length being greater ( $55.45 \mathrm{~mm}$ to $56.70 \mathrm{~mm}$ ) than diameter $(41.05 \mathrm{~mm}$ to $44.23 \mathrm{~mm}$ ).

Fruit firmness, rind weight and thickness, and pulp weight were also greatly reduced during storage (Table 1). Fruit firmness diminished 0.24 to $0.30 \mathrm{~N}$ per day, or 31 to $44 \%$ over the 20 days of storage. Rind weight was reduced by $0.39 \mathrm{~g}$ to $0.56 \mathrm{~g}$ per day, a reduction of 37 to $54 \%$ over 20 days of storage. Rind thickness was reduced by 0.05 to $0.06 \mathrm{~mm}$ per day, equivalent to 30 to $39 \%$ loss over 20 days. Pulp weight diminished by $0.25 \mathrm{~g}$ to $0.37 \mathrm{~g}$ per day, a reduction of 35 to $44 \%$ over 20 days of storage. Overall, these four traits suffered a 30 to over $50 \%$ reduction in firmness, thickness or weight over 20 days of storage.

Fruit weight loss during storage occurs due to the loss of water via transpiration. This water loss causes changes in the appearance, texture and nutritional quality of the fruit (Kader and Barrett, 2004). The loss of water provoked the formation of wrinkles in the fruit rind, which in turn resulted in the observed reduction in fruit length and diameter. However, despite fruits being completely wrinkled by the end of the 20-day storage period, fruit pulp remained intact, with a normal white color and generally in good condition. This observation has important implications for fruits used in processing rather than used for fresh fruit consumption.

Average weight of achachairú fruits in this study ( $47.8 \mathrm{~g}$ at the beginning of the storage period) was slightly less than that of the "Selecto" type from Bolivia which averaged $50.0 \mathrm{~g}$ (Ardaya, 2009), but greater than that of achachairú from Brazil which averaged $40.6 \mathrm{~g}$ (Da Fonseca, 2012). In a similar manner, fruit length $(55.7 \mathrm{~mm})$ and diameter $(41.9 \mathrm{~mm})$ in our study was somewhat smaller than the average length $(61.1 \mathrm{~mm})$ and diameter $(45.0 \mathrm{~mm})$ observed by Ardaya (2009) and greater than achachairú from Brazil $(48.0 \mathrm{~mm}$ in length and 40.2 $\mathrm{mm}$ in diameter) (Da Fonseca, 2012). Following the same trend, average pulp weight (14.8 g) and rind weight $(3.7 \mathrm{~g})$ in our study was intermediate between Ardaya's study (2009) in Bolivia and Da Fonseca's study (2012) in Brazil.

Fruits of the achachairú species from Brazil (specifically identified as G. humilis (Vahl) C. D. Adam) were also considerably rounder (length to diameter ratio of 1.17) than the fruits in our study which were more elongated (length to diameter ratio of 1.33). This latter ratio was similar to that of fruits studied by Ardaya (2009) in Bolivia (length to diameter ratio of 1.36). Ardaya (2009) also identified the species as G. humilis. It is likely that there are genetically based differences between trees from the various studies. The fruits in our study had an average rind thickness of $3.1 \mathrm{~mm}$ which was intermediate between 
that of fruits in Janick and Paull (2008) $(2.0 \mathrm{~mm})$ and Da Fonseca (2012) $(3.9 \mathrm{~mm})$. As in our study, Arjona et al. (1992) also observed a linear effect of weight loss in achachairú over storage time at various temperature levels.

Janick and Paull (2008) indicate that storage increases fruit shrinkage and firmness in achachairú, but unless fruits suffer physical damage or have been stored under too humid conditions, fruit will not rot. Previous studies on a variety of fruits, including blueberries (Proctor and Miesle, 1991), passionfruit (Aponte and Guadarrama, 2003; De la Cruz et al., 2010), avocado (Cerdas-Araya et al., 2014) and bacuri ( $P$. insignis Mart.), a native Brazilian fruit, yielded results similar to our study where firmness decreased with time in storage. These researchers suggest that loss of firmness is related to enzymatic changes in the middle lamina and cell walls of the fruits which principally consist of pectin, cellulose and hemicellulose.

\section{Full-size and atrophied seed}

Over the three harvest years there were on average 1.5 full-size seeds per fruit (Table 2). The number of seeds per fruit varied most in 2013 with 0 to 3 full-size seeds per fruit. In the other years only 1 or 2 full-size seeds per fruit were observed. Fruits also contained smaller, atrophied seeds, varying from 0 to 5 seeds per fruit and averaging 1.6 seeds per fruit. Total (full-size and atrophied) seed weight averaged $8.8 \mathrm{~g}$ over the three harvest years, or about $11 \%$ of fruit weight. The

TABLE 2.-Minimum and maximum value, mean and standard deviation (SD) of number of full-size, atrophied seed and total seed weight in samples of fruits of achachairú (Garcinia gardneriana) harvested in 2012, 2013 and 2014 in Mayagüez, Puerto Rico.

\begin{tabular}{lllll}
\hline Trait $^{z}$ & Statistic & 2012 & 2013 & 2014 \\
\hline Number of full-size seed & Minimum & 1 & 0 & 1 \\
& Maximum & 2 & 3 & 2 \\
& Mean & 1.17 & 1.98 & 1.25 \\
& SD & 0.38 & 0.62 & 0.44 \\
Number of atrophied seed & Minimum & 0 & 0 & 0 \\
& Maximum & 5 & 4 & 4 \\
& Mean & 1.88 & 1.11 & 1.95 \\
Total seed weight (g) & SD & 1.04 & 0.87 & 1.05 \\
& Minimum & 1.40 & 0.90 & 3.70 \\
& Maximum & 13.70 & 19.40 & 14.40 \\
& Mean & 7.51 & 10.43 & 8.59 \\
& SD & 2.45 & 2.77 & 1.91 \\
\hline
\end{tabular}

${ }^{\mathrm{z}} \mathrm{A}$ total of 75 fruits were sampled in 2012; 100 fruits were sampled in 2013 and 2014. 
presence of one or more large seeds in fruits of achachairú presents a challenge since consumers prefer fruits with small or no seeds. Ardaya (2009) generally observed a single full-size seed and two atrophied seeds in fruits of achachairú "Selecto" from Bolivia. The atrophied seeds were cylindrical and light brown as they also were in our study. Average seed weight in our study was greater than that in Bolivia (6.4 g) (Ardaya, 2009) and Brazil (8.25 g) (Da Fonseca, 2012).

Total Soluble Solids (TSS), Total Titratable Acid (TTA), pH, and TSS / TTA

Total soluble solids (TSS) (as measured by ${ }^{\circ} \mathrm{Brix}$ ), $\mathrm{pH}$ and the sugaracid ratio (TSS/TTA) of the pulp of achachairú fruits increased over the 20-day storage period as indicated by their consistently positive slopes (Table 3). In contrast, TTA decreased over time. The degree of change varied depending on the harvest year, but for each pulp trait, the general trend was the same. Initial values of TSS ranged from 15.43 to $16.55{ }^{\circ} \mathrm{Brix}$, and these values increased 16 to $33 \%$ over the 20 -day storage period ( 0.8 to $1.6 \%$ increase per day). Total titratable acid started at 0.69 to $0.93 \%$ citric acid and then decreased by 29 to $60 \%$ of the percentage of citric acid over 20 days (no change was observed in 2014). This corresponded to a decrease of 1.4 to $3.0 \%$ in citric acid content per day. The change in $\mathrm{pH}$ was small but significant, beginning at $\mathrm{pH} 3.41$ to 3.7 and increasing by 2 to $10 \%$ over 20 days. The sugar-acid ratio (TSS/TTA) ranged from 16.03 to 30.34 at day 0 , and then increased by 41 to $248 \%$ over the 20 -day storage period (2.1 to $12.4 \%$ increase per day).

The increase in TSS content during maturation of fruits is related to the breakup of carbohydrates stored as simple sugars which occurs during respiration (Siddiqui and Dhua, 2010). During maturation fruits become soft, change color and develop their characteristic aroma and flavor. There is also a decrease in acidity and an increase in sweetness (Wills et al., 2007; Wills et al., 1982). The reduction in acidity during maturation is a result of organic acids being used in respiration or being converted to sugars (Kader and Barrett, 2004). The sugar-acid relationship (TSS/TTA) is more often associated with the palatability of a fruit than the contents of sugar or acid by themselves (Wills et al., 1982).

The initial values of TSS in our study $\left(16.1^{\circ}\right.$ Brix, averaged over three harvest years) was somewhat lower than that observed by Da Fonseca (2012) in achachairú from Brazil (16.4 ${ }^{\circ}$ Brix) and by Ardaya (2009) in the "Selecto" type in Bolivia (16.28 ${ }^{\circ}$ Brix). The TTA in our study $(0.81 \%)$ was much less than the TTA $=1.27 \%$ reported by Da Fonseca (2012), but similar to that of Ardaya (2009) (TTA=0.80\%). Like- 


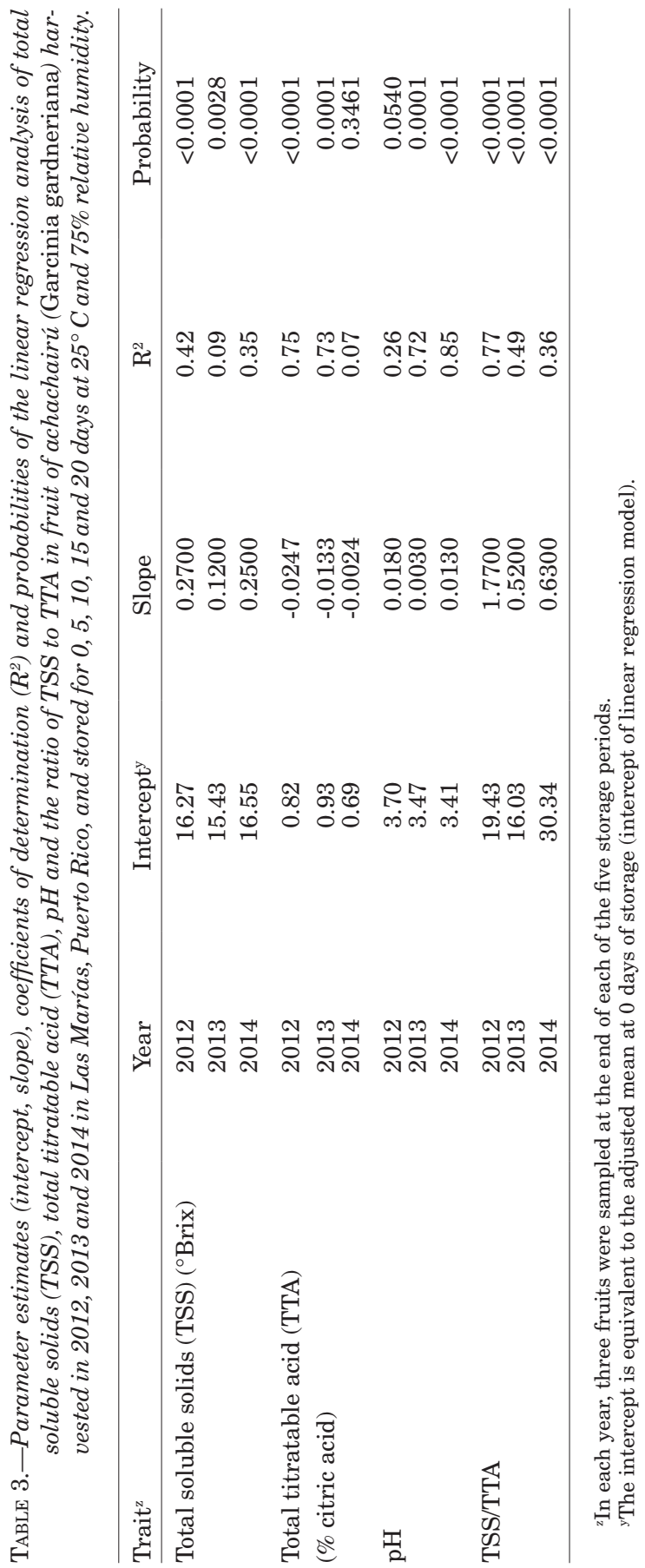


wise, $\mathrm{pH}$ in the Da Fonseca (2012) study ( $\mathrm{pH}=3.78$ ) was somewhat higher than in our study ( $\mathrm{pH}=3.53$ ). The sugar-acid ratio (TSS/TTA) in our study was 21.9 averaged over three harvest years. In comparison, fruits in the Brazilian study (Da Fonseca, 2012) had a much smaller ratio (12.65) while fruits in the Bolivian study (Ardaya, 2009) had a very similar ratio (20.35).

Palapol et al. (2009) and Castro et al. (2012) studied the effects of storage on mangosteen (G. mangostana L.), a fruit related to achachairú. In both studies, TSS increased over the 21-day storage period (from 17.2 to $17.9{ }^{\circ} \mathrm{Brix}$, and from 16 to $19^{\circ} \mathrm{Brix}$ ), an increase of 4 to $19 \%$ in TSS. In our study we observed a somewhat greater increase in TSS over 20 days, from 16 to $33 \%$.

\section{Sugars}

In at least one of two harvest years (sugars were not measured in 2012), all sugars except sucrose increased during the time that fruits were in storage (Table 4). The percentage of reducing sugars (beginning at $5.62 \%$ at day 0 in 2013 and $4.29 \%$ in 2014) consistently increased in both harvest years by a factor of $107 \%$ to $153 \%$ over the 20-day period of the experiment. Total sugar content (13.62 and 13.89 $\mathrm{g} / 100 \mathrm{~g}$ in 2013 and 2014, respectively) increased by $32 \%$ only in year 2014. There was no significant change over time in year 2013. Three sugars were identified in the pulp of achachairú: sucrose $(t=7.6 \mathrm{~min})$, glucose $(t=9.5 \mathrm{~min})$ and fructose $(t=11.8 \mathrm{~min})$. Glucose content $(4.22$ and $2.14 \mathrm{~g} / 100 \mathrm{~g}$, in 2013 and 2014, respectively) increased by $65 \%$ in year 2014 but did not change in 2013. Fructose content (4.28 and 2.49 $\mathrm{g} / 100 \mathrm{~g}$ in 2013 and 2014, respectively) did not change in 2013 and increased by $48 \%$ in 2014.

According to Chitarra and Chitarra (2005), the hydrolysis of starch, the degradation of polysaccharides of the cell walls and water loss by the fruit can all result in an increase in sugar during storage. Sucrose is metabolized during storage producing fructose and glucose (Jeffery et al., 1984). Total sugars at the beginning of our study (13.62 to $13.89 \mathrm{~g} / 100 \mathrm{~g}$ ) were less than that observed by Da Fonseca (2012) in achachairú in Brazil (16.92 g/100 g) and what was observed by Ardaya (2009) in achachairú in Bolivia (16.11 to $16.27 \mathrm{~g} / 100 \mathrm{~g})$. Sucrose content was also lower in our study ( $5.12 \mathrm{~g} / 100 \mathrm{~g}$ and $9.26 \mathrm{~g} / 100 \mathrm{~g})$ than in the Brazilian study (11.39 g/100 g) (Da Fonseca, 2012).

\section{Chemical composition}

Except for moisture content, the proximate analyses of achachairú fruit varied depending on harvest year and, in some cases, the differences among years were large (Table 5). Protein, in particular, var- 
TABLE 4.-Parameter estimates (intercept, slope), coefficients of determination $\left(R^{2}\right)$ and probabilities of the linear regression analysis of sugars in fruit of achachairú (Garcinia gardneriana) harvested in 2013 and 2014 in Las Marías, Puerto Rico, and stored for 0, 5, 10, 15 and 20 days at $25^{\circ} \mathrm{C}$ and $75 \%$ relative humidity.

\begin{tabular}{lccccc}
\hline Trait $^{\mathrm{z}}$ & Year & Intercept $^{\mathrm{y}}$ & Slope & $\mathrm{R}^{2}$ & Probability \\
\hline Reducing sugars (\%) & 2013 & 5.62 & 0.43 & 0.98 & 0.0011 \\
& 2014 & 4.29 & 0.23 & 0.93 & 0.0084 \\
Total sugars (g/100 g) & 2013 & 13.62 & 0.12 & 0.58 & 0.1358 \\
& 2014 & 13.89 & 0.22 & 0.86 & 0.0241 \\
Sucrose (g/100 g) & 2013 & 5.12 & -0.03 & 0.02 & 0.8247 \\
& 2014 & 9.26 & 0.10 & 0.69 & 0.0812 \\
Glucose (g/100 g) & 2013 & 4.22 & 0.74 & 0.27 & 0.3729 \\
& 2014 & 2.14 & 0.07 & 0.86 & 0.0242 \\
Fructose (g/100 g) & 2013 & 4.28 & 0.76 & 0.33 & 0.3074 \\
& 2014 & 2.49 & 0.06 & 0.79 & 0.0448 \\
\hline
\end{tabular}

\footnotetext{
${ }^{z}$ In each year, three fruits were sampled at the end of each of the five storage periods and their juice was bulked.

yThe intercept is equivalent to the adjusted mean at 0 days of storage (intercept of linear regression model).
}

ied from 0.42 to $0.65 \%$, fiber from 0.27 to $0.50 \%$, and ash from 0.24 to $0.51 \%$, while fat and carbohydrates showed less year-to-year variation.

The moisture percentage in "Selecto" fruits from Bolivia (Ardaya, 2009) (80 to $84 \%$ ) was somewhat greater than in our study, possibly due to differences in moisture content at the time of harvest itself. In studies by both Ardaya (2009) and Da Fonseca (2012), protein and ash content of fruits fell into a range similar to that of our study. But the fiber percentage in fruits in Ardaya's study (2009) was somewhat higher (0.56 to $1.0 \%)$, as was the percentage of fat (0.1 to $0.5 \%)$, compared to our study.

\section{Sensory analysis}

In 2012 a sensory panel of 50 persons gave fruits at day 0 an average rating of 8.3 ( 8 = "like very much") on a hedonic scale of 1 to 9 . In years 2013 and 2014 consumers rated fruits on a 1 to 7 hedonic scale at both day 0 and day 15 of storage for overall flavor and other traits (Table 6). There was no significant difference in ratings at 0 and at 15 days and all characteristics were rated between 5.7 ( 5 = "liked") and 6.4 (6 = "liked a lot").

Marsh et al. (2006) indicated that consumer fruit preferences are based on sweetness, acidity and the expectation of how a particular type of fruit should taste. We could find only one other sensory study done with a fruit similar to achachairú: Chávez-Cury et al. (2012) studied 
TABLE 5.-Proximate analysis of pulp of achachairú (Garcinia gardneriana) fruit harvested in 2012, 2013 and 2014 in Las Marías, Puerto Rico.

\begin{tabular}{|c|c|c|c|}
\hline \multirow[b]{2}{*}{ Component } & \multicolumn{3}{|c|}{ Percentage of total component ${ }^{\mathrm{z}}$} \\
\hline & 2012 & 2013 & 2014 \\
\hline Moisture & $77.70 \mathrm{a} \pm 2.73$ & $78.25 \mathrm{a} \pm 1.10$ & $77.97 \mathrm{a} \pm 0.98$ \\
\hline Protein & $0.42 \mathrm{~b} \pm 0.08$ & $0.65 \mathrm{a} \pm 0.14$ & $0.58 \mathrm{a} \pm 0.05$ \\
\hline Fiber & $0.27 \mathrm{c} \pm 0.02$ & $0.50 \mathrm{a} \pm 0.01$ & $0.32 \mathrm{~b} \pm 0.05$ \\
\hline Ash & $0.30 \mathrm{~b} \pm 0.05$ & $0.51 \mathrm{a} \pm 0.06$ & $0.24 \mathrm{c} \pm 0.02$ \\
\hline Fat & $0.08 \mathrm{a} \pm 0.02$ & $0.05 \mathrm{~b} \pm 0.01$ & $0.07 \mathrm{a} \pm 0.02$ \\
\hline Carbohydrates & 21.23 & 20.04 & 20.82 \\
\hline
\end{tabular}

${ }^{z}$ Mean of nine determinations \pm standard deviation. The nine determinations were made on a bulked sample of 10 fruits.

consumer acceptance of the sweet-sour fruit camururu (G. madruno). It was rated as "agreeable" (score of 5) to "very agreeable" (score of 6).

\section{CONCLUSIONS}

Achachairú is an exotic tropical fruit with much potential. The fruits have attractive physical and chemical traits that can make this species useful in the food industry both for fresh and processed products. As would be expected, physical traits of fruits of achachairú deteriorate over time in storage. Fruit deterioration manifests itself principally as a loss in weight, size, and firmness, all due principally to water loss over time. Most traits followed a linear (constant) progression of deterioration although the rate (slope) of deterioration varied depending on the trait. A notable exception was the case of external appearance where deterioration was curvilinear, beginning slowly and then accel-

TABLE 6.-Average sweetness, aroma, acidity, juiciness and overall flavor of achachairú (Garcinia gardneriana) harvested in 2013 and 2014 in Las Marías, Puerto Rico, and stored for 0 and 15 days at $25^{\circ} \mathrm{C}$ and $75 \%$ relative humidity. Attributes were scored on a 1 to 7 hedonic scale where $1=$ dislike extremely and $7=$ like extremely by a panel of 16 consumers in each of two years (2013 and 2014).

\begin{tabular}{lccccc}
\hline Storage period (days) & Sweetness & Aroma & Acidity & Juiciness & Overall flavor \\
\hline 0 & $6.1 \mathrm{a}$ & $5.7 \mathrm{a}$ & $5.9 \mathrm{a}$ & $6.1 \mathrm{a}$ & $6.2 \mathrm{a}$ \\
15 & $6.2 \mathrm{a}$ & $5.7 \mathrm{a}$ & $6.0 \mathrm{a}$ & $6.0 \mathrm{a}$ & $6.4 \mathrm{a}$ \\
p-value & 0.5696 & 0.8075 & 0.4860 & 0.4937 & 0.2177 \\
SE & 0.12 & 0.18 & 0.16 & 0.13 & 0.11 \\
LSD-Tukey & 0.33 & 0.51 & 0.45 & 0.36 & 0.30 \\
CV $(\%)$ & 10.63 & 17.77 & 14.90 & 11.91 & 9.49 \\
\hline
\end{tabular}

$\mathrm{SE}=$ standard error

LSD-Tukey = Tukey's least significant difference at the 0.05 probability level 
erating, especially after 15 days of storage. In contrast, traits associated with flavor, including TSS (which is mostly sugars), TTA and the sugar-acid ratio (TSS/TTA) may improve over time. Sugar concentration increased with fruit water loss over time while the percentage of citric acid (TTA) decreased over time. This resulted in a sugar-acid ratio increase of $40 \%$ to more than $200 \%$ over the 20 -day storage period. Sensory panelists rated fruits to be equally sweet, aromatic, acidic, and juicy at both 0 and 15 days of storage. Overall flavor was also rated the same at day 0 and at day 15 . Panelists apparently did not notice the increase in sweetness and decrease in acidity in stored fruit that was determined by direct measurements. Other researchers (Wills et al., 1982) have noted that it is the TSS/TTA ratio, rather than the actual percentage of sugar or acidity, which often influences consumers.

Given the excessive loss in fruit weight and firmness at 20 days of storage, and considering that consumers in sensory tests in two harvest years judged 15-day-old fruit to be as good as fresh fruit and that its external appearance remains good up to 15 days of storage at ambient temperature, we recommend that achachairú fruits be stored for no longer than this time period if they are to be used for fresh fruit consumption. For processing purposes, such as in jellies, juice or ice cream, fruits could be stored for 20 days at ambient temperature or possibly longer.

\section{LITERATURE CITED}

Achacha Fruit Management of Australia, 2013. http://achacha.com.au. Retrieved 16 Febuary 2018.

American Oil Chemists' Society (AOCS), 2004. Rapid determination of oil/fat utilizing high temperature solvent extraction. [Official Method Am 5-04]. https://www.ankom.com/sites/default/files/document-files/CrudeFat_0504_013009_1.pdf. Retrieved 16 February 2018.

Aponte, L. and A. Guadarrama, 2003. Actividad de las enzimas pectinmetilesterasa, poligalacturonasa y celulasa durante la maduración de frutos de parchita maracuyá (Passiflora edulis f. flavicarpa Degener). Revista de la Facultad de Agronomía 29(2): 145-160.

Ardaya, B.D., 2009. El cultivo de achachairú Garcinia humilis: Manual de recomendaciones. Santa Cruz de la Sierra, Bolivia: Centro de Investigación Agrícola Tropical (CIAT). pp 6-66. https://frutales.files.wordpress.com/2011/01/o20-el-cultivo-de-achacairu.pdf. Retrieved 16 February 2018.

Arjona, H.E., F.B. Matta and J.O. Garner, 1992. Temperature and storage time affect quality of yellow passion fruit. HortScience 27(7): 809-810.

Barbosa, W. and F.A. Artiole, 2007. A fruta achachairú. http://www.infobibos.com/Artigos/2007_1/achachairu/index.htm. Retrieved 16 February 2018.

Barbosa, W., E.A. Chagas, L. Martins, R. Pios, M.L.S. Tucci and F.A. Artioli, 2008. Germinação de sementes e desenvolvimento inicial de Plántulas de Achachairú. Revista Brasileira de Fruticultura, Jaboticabal 30(1): 263-266.

Barragán-Arce, M., 2011. To be or not to be: Conjetures on the identity of an exotic Garcinia found in Puerto Rico based on observations of its floral morphology. Puerto Ri- 
can Society of Agricultural Sciences Annual Meeting, November 2011. Puerto Rico. Abstract.

Castro, M.F.P.P.M., V.D.D.A. Anjos, A.C.B. Rezende, E.A. Benato and S.R.D.T. Valentini, 2012. Postharvest technologies for mangosteen (Garcinia mangostana L.) conservation. Food Science and Technology 32(4): 668-672. doi: 10.1590/S010120612012005000103

Cavalcante, I.H.L., N.D. Jesus and A.B.G. Martins, 2006. Physical and chemical characterization of yellow mangosteen fruits. Revista Brasileira de Fruticultura 28(2): 325-327.

Cerdas-Araya, M.D.M., M. Montero-Calderón and O. Somarribas-Jones, 2014. Verificación del contenido de materia seca como indicador de cosecha para aguacate (Persea americana) cultivar Hass en zona intermedia de producción de Los Santos, Costa Rica. Agronomía Costarricense 38(1): 207-214.

Chávez-Cury, G., M.D.C. Abela-Gisbert, J.A. Bravo, J.M. Peñarrieta and W.J. RendónPorcel, 2012. Estudio del fruto comestible de la especia vegetal Garcinia madruno. Revista Boliviana de Química 29(1): 87-93.

Chitarra, M.I.F. and A. B. Chitarra, 2005. Pós-colheita de frutas e hortaliças: Fisiología e manuseio. Lavras, Brazil: UFLA.

Da Fonseca, M. R., 2012. Caracterização qualitativa de frutos de achachairu [Garcinia humilis (Vahl) C. D. Adam] cultivados en Moreno-PE. M.S. Thesis, Universidade Federal Rural de Pernambuco, Recife-PE, Brasil. pp13-56. http://www.tede2.ufrpe. br:8080/tede/bitstream/tede2/5091/2/Maria\%20Rafaella\%20da\%20Fonseca\%20Pimentel.pdf. Retrieved 16 February 2018.

De la Cruz, J., M. Vargas, O. Del Angel and H.S. García, 2010. Estudio de las características sensoriales, fisicoquímicas y fisiológicas en fresco y durante el almacenamiento refrigerado de maracuyá amarillo (Passiflora edulis Sims var. Flavicarpa. Degener), para tres cultivares de Veracruz México. Revista Iberoamericana de Tecnología Postcosecha 11(2): 130-142.

Deman, J.M., 1999. Principles of Food Chemistry. Third Edition. Gathersburg, MD, USA: Aspen.

Duarte, O., 2011. Achachairú [Garcinia humilis (Vahl) C. D. Adam]. In: E. M. Yahia (ed) Postharvest Biology and Technology of Tropical and Subtropical Fruits. Vol. 2: Açai to Citrus. Woodhead Publishing Series in Food Science, Technology and Nutrition, Cambridge, United Kingdom.

Fontenele, M.A., 2007. Conservação pós-colheita do bacuri sob condições ambiente e refrigeração associada à atmosfera modificada. Pp 57-139, M.S. Thesis, Universidade Federal Do Ceará, Fortaleza, Brasil. http://www.ppgcta.ufc.br/mariaalves.pdf. Retrieved 16 February 2016.

Gutiérrez, J.B., 2000. Ciencia Bromatológica: Principios generales de los alimentos. Madrid, España: Ediciones Díaz de Santos. p 326.

Horwitz, W. and AOAC International, 2003. Official Methods of Analysis of the AOAC International (17 th ed.). Gaithersburg: AOAC International.

International Plant Names Index, 2019. http://www.ipni.org/ipni/idPlantNameSearch. do?id=972610-1. Retrieved 25 January 2019.

International Tropical Fruits Network, 2019. http://www.itfnet.org/v1/2018/05/australiaworlds-largest-achacha-plantation-for-sale/. Retrieved 28 January 2019.

Janick, J. and R. E. Paull, 2008. The encyclopedia of fruits and nuts. Cambridge, MA, USA: CABI. pp. 272-273. doi: 10.1525/bio.2009.59.8.19

Jeffery, D., P. Smith, I. Goodenough, I. Prosser and D. Grierson, 1984. Ethylene independent and ethylene dependent biochemical changes in ripening tomatoes. Plant Physiology 74(1): 32-38.

Kader, A.A. and D.M. Barrett, 2004. Classification, composition of fruits, and postharvest maintenance of quality. In: Barrett, D. M., L. Somogyi and H. S. Ramaswamy, (Eds.), Processing fruits: Science and technology. Second Edition. Davis, CA, USA: CRC Press. pp. 3-22.

Lim, T.K., 2012. Edible medicinal and non-medicinal plants. Fruits 2: 60. doi:10.1007/97894-007-1764-0. 
Marsh, K.B., E.N. Friel, A. Gunson, C. Lund and E. MacRae, 2006. Perception of flavour in standardized fruit pulps with additions of acids or sugars. Food quality and preference 17(5): 376-386. doi: 10.1016/j.foodqual.2005.04.011

Meilgaard, M.C., B.T. Carr and G.V. Civille, 2007. Sensory evaluation techniques. Fourth Edition. CRC Press. pp 275-279.

Palapol, Y., S. Ketsa, D. Stevenson, J. M. Cooney, A.C. Allan and I.B. Ferguson, 2009. Colour development and quality of mangosteen (Garcinia mangostana L.) fruit during ripening and after harvest. Postharvest Biology and Technology 51: 349-353. doi:10.1016/j.postharvbio.2008.08.003

Pantastico, E.R.B., T.K. Chattopadhyay and H. Subramanyam, 1979. Almacenamiento y operaciones comerciales de almacenaje. In: Pantastico, ER. B. (Ed.). Fisiología de la postrecolección, manejo y utilización de frutas y hortalizas tropicales y subtropicales. México: Compañía Editorial Continental. pp 375- 405.

Proctor, A. and T.J. Miesle, 1991. Polygalacturonase and pectinmethylesterase activities in developing highbush blueberries. HortScience 26(5): 579-581.

Salman, M., M.T. Alghamdi, S.A. Bazaid and E.S. Abdel-Hameed, 2011. Determination of fructose, glucose and sucrose in taif grape using high performance liquid chromatography and analysis of mineral salts. Archives of Applied Science Research 3(6): 488-496.

Siddiqui, M.W. and R.S. Dhua, 2010. Eating artificially ripened fruits is harmful. Current Science 99(12): 1664-1668.

Teixeira, G.H.D.A., J.F. Durigan, M.A. Lima, R.E. Alves and H.A.C. Filgueiras, 2005. Postharvest changes and respiratory pattern of bacuri fruit (Platonia insignis Mart.) at different maturity stages during ambient storage. Acta Amazônica 35(1): 17-21. doi:10.1590/S0044-59672005000100003

Thorp, T.G and R. Bieleski, 2002. Feijoas: origins, cultivation and uses. Auckland, New Zealand: David Bateman. p 87.

Wills, R.B.H., T.H. Lee, D. Graham, W.B. McGlasson and E.G. Hall, 1982. Postharvest: An introduction to the physiology and handling of fruit and vegetables. Second Edition. Kensington, Australia: AVI. pp 19-94.

Wills, R.B.H., W.B. McGlasson, D. Grahm and D.C. Joyce, 2007. Physiology and biochemistry. In: Postharvest: An introduction to the physiology and handling of fruit, vegetables and ornamentals. pp 28-51. Sydney, Australia: UNSW. 